\begin{tabular}{|c|c|c|}
\hline $\begin{array}{l}\text { OPEN ACCESS } \\
\text { Vol. } 3 \text { No. 1: 18-22 } \\
\text { Tahun 2019 } \\
\text { Artikel penelitian 固 }\end{array}$ & $\begin{array}{c}\text { Jurrnal Alkudililestari } \\
\text { E-ISSN: 2598-8204 } \\
\text { https://ojs.umrah.ac.id/index.php/akuatiklestari } \\
\text { DoI : https://doi.org/10.31629/akuatiklestari.v3i1.974 }\end{array}$ & $Q=$ \\
\hline
\end{tabular}

\title{
Tingkat Kesuburan Perairan Danau Pasca Tambang Timah di Desa Prayun Kecamatan Kundur Kabupaten Karimun
}

\author{
Trophic Level of Tin Post Mining in Prayun Kundur Karimun District
}

\author{
Juliana ${ }^{\circledR}$, Winny Retna Melani'1, Dedy Kurniawan'1 \\ ${ }^{1}$ Manajemen Sumberdaya Perairan, Fakultas Ilmu Kelautan dan Perikanan, Universitas Maritim Raja Ali Haji, Tanjungpinang, \\ Indonesia 29111
}

\section{$\square$ Info Artikel:}

Diterima: 29 Januari 2019

Revisi: 20 Februari 2019

Disetujui: 30 Oktober 2019

Dipublikasi: 30 November 2019

\section{[Deyword:}

Kesuburan Perairan, Tambang Timah, Desa Prayun, TSI

\footnotetext{
$\bowtie$ Penulis Korespondensi:

Julaiana

Manajemen Sumberdaya Perairan Fakultas Ilmu Kelautan dan Perikanan Universitas Maritim Raja Ali Haji Tanjungpinang 29111 Email: julianay04@gmail.com
}

\begin{abstract}
ABSTRAK. Kepulauan Kundur merupakan salah satu penghasil timah di Indonesia, salah satu lokasinya berada di Desa Prayun. Desa Prayun terdapat banyak bekas galian tambang timah yang dibiarkan begitu saja tanpa termanfaatkan. Tujuan penelitian ini adalah untuk mengetahui tingkat kesuburan perairan Pasca Tambang Timah Desa Prayun Kecamatan Kundur Kabupaten Karimun. Penelitian ini dilakukan di Desa Prayun Kepulauan Kundur pada bulan Maret-Juni 2018. Penelitian ini mengunakan metode survei, dengan penentuan stasiun menggunakan metode Random Sampling sebanyak 30 titik. Data kualitas perairan yang diamati antara lain suhu, kecerahan, pH, DO (Oksigen Terlarut), BOD (Biochemical Oxygen Demand), $\mathrm{NO}_{3}$ (Nitrat), P (Fosfat), dan Klorofil-a. Data konsentrasi fosfat total (TSI-P), konsentrasi klorofil-a (TSI-Chl-a), dan nilai kecerahan (TSI-SD) yang diperoleh, dianalisis menggunakan metode Trofik Status Indeks (TSI) untuk mendapatkan nilai tingkat kesuburan perairan. Hasil penelitian ini didapatkan nilai TSI 35,1357 yang menunjukkan bahwa perairan di danau pasca tambang timah Desa Prayun ini tergolong dalam kategori oligotrofik (kesuburan rendah).
\end{abstract}

ABSTRACT. The Kundur Islands are one of the tin producers in Indonesia, one of which is in Prayun Village. Prayun Village has many unused tin mining excavations. The purpose of this study was to determine the level of post-tin mining fertility in Prayun Village, Kundur District, Karimun Regency. This research was conducted in the village of Prayun Kepulauan Kundur in March-June 2018. This study used a survey method, with the determination of the station using the Random Sampling method of 30 points. Water quality data observed included temperature, brightness, $\mathrm{pH}, \mathrm{DO}$ (Dissolved Oxygen), $\mathrm{BOD}$ (Biochemical Oxygen Demand), $\mathrm{NO}_{3}$ (Nitrate), P (Phosphate), and Chlorophyll a. Total phosphate concentration (TSI-P), chlorophylla concentration (TSI-Chl-a), and brightness value (TSI-SD) were analyzed using the Trophic Status Index (TSI) method to obtain water fertility values. The results of this study obtained a TSI value of 35.1357 which indicates that the waters in the post-tin mining lake of Prayun Village are classified as oligotrophic (low fertility).

\section{How to cite this article:}

Juliana, Melani, R,W., \& Kurniawan, D. (2019). Tingkat Kesuburan Perairan Danau Pasca Tambang Timah di Desa Prayun Kecamatan Kundur Kabupaten Karimun.. Jurnal Akuatiklestari, 3(1): 18-22. https://doi.org/10.31629/akuatiklestari.v3i1.974

\section{PENDAHULUAN}

Kepulauan Kundur merupakan salah satu penghasil timah di Indonesia. Salah satu bekas galian timah di Pulau Kundur dimanfaatkan oleh warga sebagai tempat wisata, yang dikenal sebagai “Danau Bebek", dengan luas total danau 257.032,73 $\mathrm{m}^{2}$. PT Timah mempunyai kuasa untuk melakukan penambangan baik di darat dan di lautan dengan luas total \pm 522.640 hektar di Kepulauan Riau (Pulau Karimun, Kundur, Singkep dan Kepulauan Bangka Belitung), PT. Timah menjadi eksportir timah terbesar di Indonesia. Sabuk timah membentang mulai dari Burma Tengah hingga Tenasserim dan berlanjut ke selatan meliputi Thailand Barat, Semenanjung Malaya Barat, Pulau Karimun, Kundur, Singkep, Bangka, Belitung, Pulau Karimata, dan berakhir di Kalimantan Barat (Sujitno 2007).

Deposit timah didaratan Kundur mulai berkurang drastis, PT. Timah memulai eksploitasi timah di lautan. Untuk mengambil timah di dasar laut PT Timah mengunakan kapal isap dan kapal keruk yang dilengkapi dengan "mangkuk". Mangkuk ini dapat beroperasi mulai dari 15 sampai 50 meter dibawah permukaan laut dengan kemampuan gali mencapai lebih dari 3,5 juta $\mathrm{m}^{2}$ material setiap bulannya. Untuk meningkatkan kapasitas produksi di 
laut, PT. Timah membuat kapal isap dengan kemampuan gali mencapai 25 meter di bawah permukaan laut sehingga dapat menjangkau cadangan sisa dari kapal keruk.

Bekas penggalian timah didaratan dibiarkan begitu saja membentuk sebuah danau buatan dengan pancaran air yang jernih. Lahan bekas galian timah dijadikan sebagai area perikanan yang produktif bila dikelola secara baik sesuai dengan karakteristik lahannya (Apriadi et al., 2017). Untuk dapat dikembangkan sebagai lahan yang produktif dan berkelanjutan, perlu terlebih dahulu diketahui tingkat kesuburan perairan, sehingga pengelolaannya lebih tepat (Ismail et al., 2018; Fauzan et al., 2018; Hasniar et al., 2018). Tujuan penelitian ini adalah untuk mengetahui tingkat kesuburan perairan Pasca Tambang Timah Desa Prayun Kecamatan Kundur Kabupaten Karimun.

\section{BAHAN DAN METODE}

\subsection{Waktu dan Tempat}

Penelitian dilakukan pada bulan Maret 2017 - Januari 2018. Penelitian dilakukan di Desa Prayun Kecamatan Kundur Kabupaten Karimun. Pengamatan sample secara ex situ dilakukan untuk analisis $\mathrm{NO}_{3}$ (Nitrat) dan P (Fosfat) dilakukan di Laboratorium Balai Teknik Kesehatan Lingkungan (BTKL) Batam, sedangkan untuk analisis konsentrasi BOD dan klorofil-a dilakukan di Laboratorium Fakultas Ilmu Kelautan dan Perikanan Universitas Maritim Raja Ali Haji. Lokasi penelitian dapat dilihat pada Gambar 1.
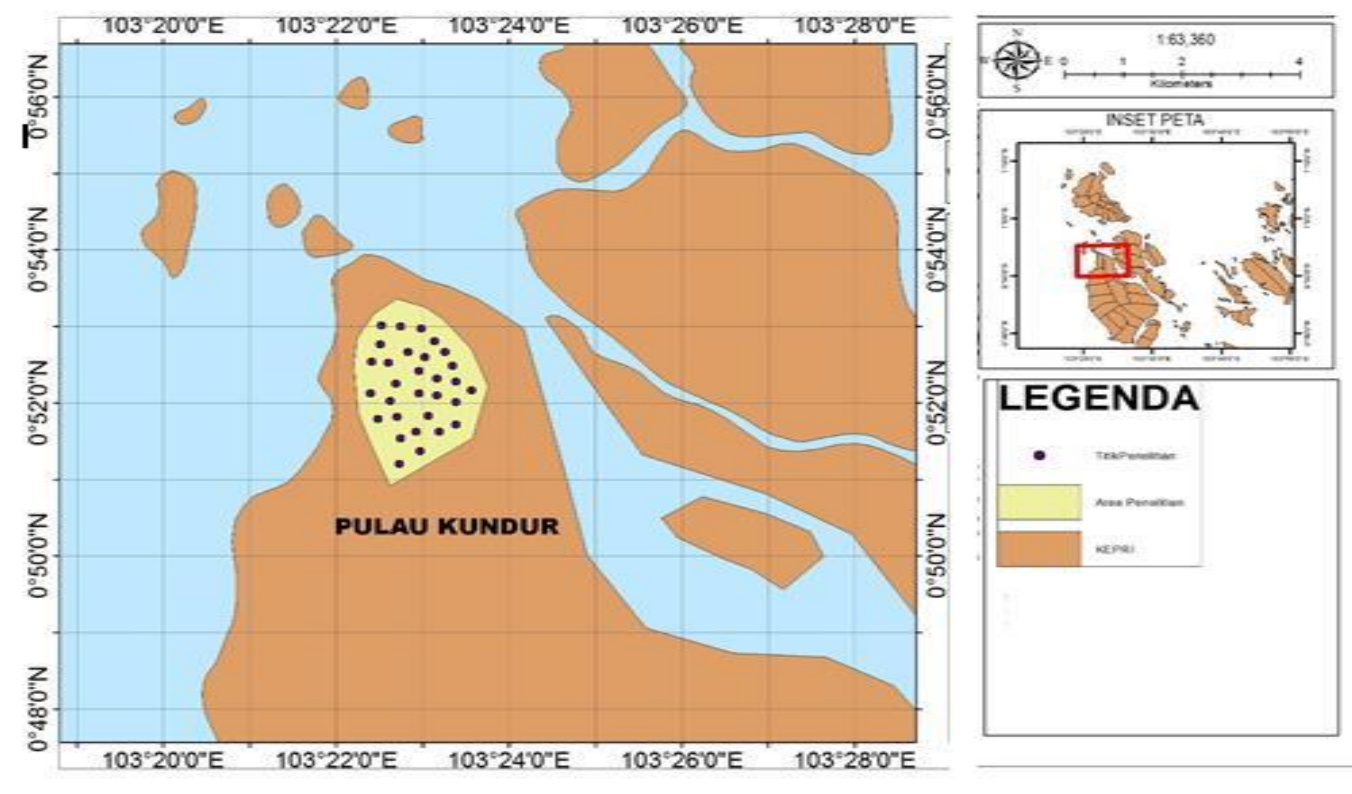

Gambar 1. Lokasi Penelitian Desa Prayun

\subsection{Alat dan Bahan}

Alat dan bahan yang digunakan dalam penelitian ini berupa alat dan bahan yang digunakan untuk pengambilan sampel air kualitas perairan, serta pengukuran parameter perairan. Alat yang digunakan pada penelitian ini yaitu: GPS (Global Positioning System) sebagai penentu posisi objek yang diamati; multitester untuk mengukur suhu, pH, DO; botol sampel untuk menyimpan sampel air; cool box digunakan sebagai tempat menyimpan sampel air; secchi disc untuk mengukur kecerahan; peralatan titrasi untuk mengukur $\mathrm{BOD}_{5}$; inkubator untuk mengukur $\mathrm{BOD}_{5}$; erlenmeyer untuk mengukur $\mathrm{BOD}_{5}$; colorimeter untuk mengukur nitrat; spektrofotometer untuk mengukur fosfat, klorofil-a; kamera sebagai alat dokumentasi.

Bahan yang digunakan dalam penelitian ini antara lain sampel air untuk analisis klorofil-a, nitrat, ortofosfat; aseton 90\% untuk melarutkan kertas saring (klorofil-a); kertas saring milipore untuk menyaring sampel; centrifuge 5430 Eppendrof untuk mengendapkan kertas saring; peralatan glass (tabung reaksi, pipet dan lain-lain) untuk proses analisis klorofil-a; kertas label sebagai penanda sampel air; dan alat tulis menulis untuk mencatat data di lapangan dan dilaboratorium.

\subsection{Prosedur Penelitian}

\subsubsection{Penentuan Titik Pengamatan}

Penentuan titik sampling dalam penelitian ini menggunakan metode random sampling atau metode acak, penggunaan metode acak ini diambil karena perairannya yang cenderung homogen atau memiliki sifat dan karakteristik yang sama, serta diharapkan dapat mewakili wilayah kajian, sehingga data yang terambil mampu memberikan gambaran yang jelas mengenai keadaan perairan danau pasca tambang timah Desa Prayun Kecamatan 
Kundur Kabupaten Karimun. Pengambilan sampel diambil sebanyak 30 titik pengamatan yang diacak mengunakan Visual Sampling Plan (VSP) dengan Software Arc.GIS 10.3.

\subsubsection{Pengambilan Parameter Perairan}

Parameter perairan dilakukan pada 30 titik pengamatan di perairan danau pasca tambang timah Desa Prayun Kecamatan Kundur Kabupaten Karimun. Parameter yang diamati meliputi suhu perairan dengan menggunakan termometer, kecerahan perairan dengan menggunakan secchi disc, $\mathrm{pH}$ (derajat keasaman) dengan menggunakan $\mathrm{pH}$ meter, $\mathrm{DO}$ dengan menggunakan multitester, pengukuran $\mathrm{BOD}_{5}$ dan Klorofil a dilakukan di Laboratorium Fakultas Ilmu Kelautan dan Perikanan Universitas Maritim Raja Ali Haji, serta pengukuran Nitrat dan Fosfat dilakukan di Laboratorium Balai Teknik Kesehatan Lingkungan (BTKL) Batam.

\subsection{Analisis Data}

Tingkat kesuburan perairan danau dihitung berdasarkan beberapa parameter yang sangat berpengaruh terhadap kesuburan danau sesuai dengan perhitungan Trophic States Index (TSI) yang dikemukakan oleh Carlson (1977). TSI didasarkan pada tiga parameter yaitu konsentrasi fosfat total (TSI-P), konsentrasi klorofil-a (TSI-Chl-a) dan nilai kedalaman Secchi disk (TSI-SD). Tingkat kesuburan perairan danau dihitung berdasarkan perhitungan Trophic State Index (TSI) Carlson (1977) sebagai berikut :

$$
\text { Rata }- \text { rata TSI }=\frac{((\text { TSI }-\mathbf{P})+(\text { TSI }- \text { Chl }-\mathbf{a})+(\text { TSI }- \text { SD }))}{3}
$$

Keterangan:

TSI-P = Nilai trofik status indeks untuk fosfat

TSI-Chl-a = Nilai trofik status indeks untuk klorofil-a

TSI-SD = Nilai trofik status indeks untuk kedalaman secchi disk

Data hasil perhitungan indeks TSI Carlson (1977), dikelompokkan sebagaimana yang disajikan pada Tabel 1.

Tabel 1. Kategori Status Kesuburan Berdasarkan Perhitungan TSI Carlson

\begin{tabular}{ccccc} 
TSI & Chl-a & P & SD & Status Kesuburan \\
$<30-40$ & $0-2.6$ & $0-12$ & $>8-4$ & Oligotrofik \\
$<40-50$ & $2.6-7.3$ & $12-24$ & $4-2$ & Mesotrofik \\
$<50-70$ & $7.9-56$ & $24-96$ & $2-0.5$ & Eutrofik \\
$<70-100+$ & $56-155+$ & $96-384+$ & $0.5-<0.25$ & Hyper-eutrofik \\
\hline
\end{tabular}

\section{HASIL DAN PEMBAHASAN}

\subsection{Kondisi Lingkungan Perairan Desa Prayun}

Hasil penelitian di danau pasca tambang timah Desa Prayun, nilai rata-rata yang diperoleh dibandingkan dengan baku mutu pada Peraturan Pemerintah Nomor 82 tahun 2001 tentang Pengelolaan Kualitas Air dan Pengendalian Pencemaran kelas 2. Hasil Penelitian yang didapat disajikan pada Tabel 2.

Tabel 2. Hasil Pengukuran Parameter Kualitas Perairan

\begin{tabular}{lcccc} 
Parameter & Satuan & Kisaran & Rata-rata & Baku Mutu* \\
Fisika & & & \\
Suhu & ${ }^{\circ} \mathrm{C}$ & $30,1-31,8$ & $31,0 \pm 0,2$ & Deviasi 3 \\
Kecerahan & $\mathrm{M}$ & $1,45-1,49$ & $1,47 \pm 0,04$ & - \\
Kimia & & & $4,6 \pm 0,07$ & $6-9$ \\
pH & & $4,2-4,9$ & $6,8 \pm 0,02$ & 4 \\
DO & $\mathrm{mg} / \mathrm{L}$ & $6,6-7,2$ & $2,1 \pm 0,02$ & 2 \\
BOD & $\mathrm{mg} / \mathrm{L}$ & $1,7-2,2$ & $0,12 \pm 0,05$ & 10 \\
Nitrat & $\mathrm{mg} / \mathrm{L}$ & $0-0,18$ & $0,21 \pm 0,0002$ & 0,2 \\
Fosfat & $\mathrm{mg} / \mathrm{L}$ & $0,19-0,23$ & & - \\
Biologi & & & $2,964 \pm 0,73$ & \\
Klorofil-a & $\mathrm{mg} / \mathrm{L}$ & $2,215-3,596$ & & \\
\hline
\end{tabular}

*PP No.82 Tahun 2001 (Kelas 2) 
Nilai suhu selama penelitian yaitu berkisar antara $30,1-31,8^{\circ} \mathrm{C}$, nilai suhu disetiap titik pengambilan sampel relatif stabil, dan masih sesuai dengan baku mutu yang ditetapkan. Pengukuran suhu dilakukan pada pagi menjelang siang hari dan pada kondisi cuaca yang normal. Nilai suhu tidak berbanding jauh dengan masing-masing titik dikarenakan karakteristik perairan danau pasca tambang timah ini relatif sama. Nilai suhu paling rendah berada di titik 3 dengan nilai 30,1 dan paling tinggi berada di titik 14, 15 dan 25 dengan nilai 31,7. Suhu tinggi dibeberapa titik dikarenakan area yang dangkal sehingga intensitas cahaya yang diterima cukup tinggi. Menurut Wardhana (2004), tinggi rendahnya suhu dipengaruhi oleh sinar matahari dan kondisi air, kenaikan suhu air dapat menyebabkan, jumlah oksigen terlarut didalam air menurun, kecepatan reaksi kimia meningkat, dan kehidupan makhluk hidup didalamnya terganggu.

Nilai kecerahan selama penelitian yaitu berkisar antara 1,45-1,49 m. Nilai kecerahan pada setiap titik tidak berbeda jauh. Nilai kecerahan sangat ditentukan oleh partikel-partikel terlarut dan lumpur. Semakin banyak partikel atau bahan organik terlarut maka kekeruhan akan meningkat kecerahan pun berkurang. Di sekitar danau pasca tambang tersebut tidak adanya aktifitas dari masyarakat sehingga tidak ada bahan organik yang masuk ke perairan, sehingga nilai kecerahan tinggi. Menurut Effendi (2003), tingkat kecerahan suatu perairan mengindikasikan terjadinya proses fotosintesis pada tumbuhan yang hidup di sekitar perairan tersebut dan menghasilkan nutrient bagi organisme- organisme akuatik di sekitar perairan.

Nilai pH tidak memenuhi batas baku mutu yang ditetapkan, nilai $\mathrm{pH}$ saat penelitian yiatu berkisar 4,2-4,9 pH jauh lebih rendah di bandingkan dengan baku mutu yaitu 6-9, itu artinya $\mathrm{pH}$ di perairan tersebut sangat asam. $\mathrm{pH}$ rendah diduga karena umur danau yang tergolong sedang yaitu 15 tahun, kategori dengan umur <5-20 masih terdapat bahan pencemar. pH rendah juga diduga dari proses penambangan timah dari hasil oksidasi secara alami dari mineral sulfida, khususnya senyawa Cassiterite. Proses oksidasi cassiterite dimulai ketika cassiterite dari dalam tanah terangkat kepermukaan tanah dan bereaksi dengan air dan oksigen, proses itu lah yang menyebabkan pelepasan asam (Whardana, 2004).

Nilai DO berkisar 6,6-7,2 mg/L, untuk perairan normal kandungan DO dengan rentang tersebut cukup untuk mendukung kehidupan organisme perairan. Oksigen terlarut di suatu perairan juga sangat berperan dalam proses penyerapan makanan oleh makhluk hidup dalam air. Semakin banyak jumlah DO maka kualitas air semakin baik. Jika kadar oksigen terlarut yang terlalu rendah akan menimbulkan bau yang tidak sedap akibat degradasi yang mungkin saja terjadi. Oksigen terlarut dibutuhkan oleh semua organisme hidup untuk pernapasan, proses metabolisme atau pertukaran zat yang kemudian menghasilkan energi untuk pertumbuhan dan perkembangbiakan (Darmono, 2001).

BOD yang didapat pada saat penelitian yaitu 1,7-2,2 $\mathrm{mg} / \mathrm{L}$ dari nilai baku mutu yang telah ditetapkan yaitu 2 $\mathrm{mg} / \mathrm{L}$, dari rentang tersebut perairan danau mampu untuk mendukung kehidupan organisme. Nilai BOD menunjukkan jumlah oksigen terlarut yang di butuhkan oleh mikroorganisme hidup untuk memecah atau mengoksidasi bahan organik di dalam air. Menurut Haryanto (2004), Semakin tinggi nilai BOD berarti semakin besar derajat pengotoran air limbah oleh bahan organic.

Nilai nitrat dari hasil penelitian adalah $0-0,18 \mathrm{mg} / \mathrm{L}$, berdasarkan nilai tersebut kandungan nitrat masih rendah dibandingkan dengan baku mutu yang ditetapkan. Nitrat yang rendah diduga karena kandungan bahan organik yang rendah karena tidak adanya aktifitas di sekitar danau, penyumbang nutrient hanya didapat dari proses dekomposisi serasahnya pohon yang berada disekitar danau (guguran daun, bunga, buah, ranting dan sejumlah bagian pohon lain yang jatuh) menjadi nitrat oleh batuan mikroba (Apriadi et al., 2019; Yuliana, 2012).

Nilai fosfat dari hasil penelitian adalah 0,19-0,23 mg/L, nilai fosfat masih sesuai dengan baku mutu yang di tentukan, yaitu 0,2 mg/L. Fosfat terdapat pada proses penambangan timah, karena proses penambangan timah salah satunya adalah mencuci tanah yang mengandung timah dengan air sehingga mengakibatkan tanah yang mengandung fosfor larut ke dalam air. Selain dari pencucian kandungan timah, fosfat juga terdapat pada serasah pohon yang berada disekitar danau yang telah mengalami dekomposisi manjadi bahan organik maupun anorganik dengan batuan bakteri, merupakan salah satu sumber masukan fosfat bagi perairan sekitar (Apriadi et al., 2018; Bahri, 2006).

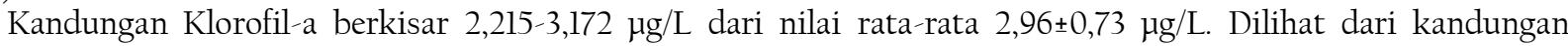
klorofil-a, perairan danau pasca tambang timah Desa Prayun tergolong perairan dengan tingkat kesuburan sedang, perairan dengan konsentrasi klorofil-a $<2 \mu \mathrm{g} / \mathrm{L}$ dikategorikan ke dalam perairan oligotrophik, perairan dengan konsentrasi klorofil-a 2-6 $\mu \mathrm{g} / \mathrm{L}$ dikategorikan ke dalam perairan mesotrophik, perairan dengan konsentrasi klorofil-a 6-20 $\mu \mathrm{g} / \mathrm{L}$ dikategorikan ke dalam perairan eutrophik, perairan dengan konsentrasi klorofil-a >20 $\mu \mathrm{g} / \mathrm{L}$ dikategorikan ke dalam perairan hipotrophik (Hasibuan, 2001).

\subsection{Tingkat Kesuburan Perairan}

TSI merupakan suatu metode sederhana yang dapat digunakan untuk menentukan suatu tingkat kesuburan perairan dengan menggunakan tiga parameter yang saling berkaitan yaitu kecerahan, fosfat dan klorofil-a. Hasil analisis yang diperoleh maka perairan danau pasca tambang timah Desa Prayun termasuk dalam perairan Oligotrofik (kurang subur) dengan nilai TSI yaitu 35,1375. Danau pasca tambang timah kurang subur diduga karena kandungan bahan organik yang rendah disebabkan tidak adanya aktivitas disekitar danau. Sumber utama nitrogen di perairan berasal dari limbah yang mengandung senyawa nitrat yang berupa bahan organik dan bahan anorganik seperti pupuk nitrogen, sedangkan nitrogen merupakan unsur yang sangat penting bagi pertumbuhan fitoplankton dan merupakan salah satu unsur utama dalam pembetukan protein dan selanjutnya menjadi sumber 
makanan bagi organisme disekitar perairan. Selain tidak adanya masukan, danau kurang subur juga diduga karena $\mathrm{pH}$ yang rendah, $\mathrm{pH}$ rendah diduga karena umur danau yang tergolong sedang yaitu 15 tahun, kategori dengan umur <5-20 masih terdapat bahan pencemar, dan juga dari proses penambangan timah dari hasil oksidasi secara alami dari mineral sulfida, khususnya senyawa Cassiterite, proses itu lah yang menyebabkan pelepasan asam. Menurut Effendi (2003), oligotofik merupakan status trofik air yang mengandur unsur hara dengan kadar rendah dalam menentukan status trofik suatu perairan tergantung pada penyebaran konsentrasi klorofil-a dan ketersediaan nutrient (nitrogen dan fosfor).

\section{SIMPULAN} 35,1375 .

Tingkat kesuburan perairan berdasarkan nilai TSI tergolong oligotrofik (kurang subur) dengan nilai TSI yaitu

\section{REFERENSI}

Apriadi, T., Pratama, G., Arpas, H. D., \& Ashari, I. H. (2017). Struktur Komunitas Fitoplankton pada Daerah Pascatambang Bauksit dan Lahan Basah Alami di Pulau Bintan. Jurnal Akuatiklestari, 1(1): 14-20. https://doi.org/10.31629/akuatiklestari.vlil.2355

Apriadi, T., Pratama, G., Putra, R.D., Jumsurizal, Jaya, V.J., Firdaus, M., Arpas, H.D., \& Suryanti, A. (2018). Comparative study on the fish diversity from natural and bauxite post-mining in wetland system of Bintan Island, Indonesia. Biodiversitas Journal of Biological Diversity, 19(3): 967-973. https://doi.org/10.13057/biodiv/d190327

Apriadi, T., Putra, R.D., \& Idris, F. (2019). Produktivitas Primer Perairan Kolong Bekas Tambang Bauksit di Kota Tanjungpinang, Kepulauan Riau. Oseanologi dan Limnologi di Indonesia, 4(2): 113-121. https://doi.org/10.14203/oldi.2019.v4i2.246

Carlson, R.E. (1977). A Trophic State Index for Lakes. Limnology and Oceanography, 22(2): 361-369. https://doi.org/10.4319/10.1977.22.2.0361

Darmono. (2001). Lingkungan Hidup dan Pencemaran, Hubungannya dengan Toksikologi Senyawa Logam. [Skripsi]. Universitas Indonesia. Jakarta.

Effendi, H. (2003). Telaah Kualitas Air Bagi Pengelolaan Sumberdaya dan dLingkungan Perairan. Yogjakarta.

Fauzan, A., Melani, W. R., \& Apriadi, T. (2018). Tingkat Kesuburan Perairan di Perairan Tembeling Tanjung, Kabupaten Bintan, Provinsi Kepulauan Riau. Jurnal Akuatiklestari, 2(1): 22-28. https://doi.org/10.31629/akuatiklestari.v2il.2349

Hasibuan. (2001). Dampak Pencemaran Lingkungan. Badan Kerjasama Perguruan Tinggi Negeri. Indonesia Bagian Timur. Mann \& lazier 1991. Limnology. McGraw-Hill Book Company. Tokyo.

Hasniar, R., Melani, W. R., \& Apriadi, T. (2018). Status Perairan Kampung Madong, Kota Tanjungpinang. Jurnal Akuatiklestari, 2(1): 29-35. https://doi.org/10.31629/akuatiklestari.v2il.2350

Ismail, Melani, W. R., \& Apriadi, T. (2018). Tingkat Kesuburan Perairan di Perairan Kampung Madong, Kelurahan Kampung Bugis, Kota Tanjungpinang. Jurnal Akuatiklestari, 2(1): 9-13. https://doi.org/10.31629/akuatiklestari.v2il.931

Sujitno, S. (2007). Sejarah Penambangan Timah di Indonesia Abad ke 18-abad ke 20. PT Timah. Pangkalpinang.

Wardhana. (2010). Model Pengembangan Kolong Terpadu Pasca Penambangan Timah di wilayah Bangka Belitung. Majalah Ilmiah Sriwijaya.

Yuliana. (2012). Planton dan Produktifity. In the ocean pergamon press. New York. 